\title{
The influence of flood pulse on fish communities of floodplain canals in the Middle Solimões River, Brazil
}

\author{
Raniere G. C. Sousa and Carlos E. de C. Freitas
}

The functioning of large river systems with adjacent floodplains is strongly influenced by the flood pulse. This phenomenon is the main structuring force for the biota, including fish communities that use floodplain environments for spawning, feeding, nursery and refuge. In floodplains and in the entire basin, the volume of water controls internal flows. During rising water, the high discharge of the river acts as a natural barrier to the canals that connect floodplain lakes and the Solimões River, because the water flows from river to lake. During the dry period, there is a reduction of discharge and the water flow is reversed or stationary. These canals are environments with distinct ecological characteristics such as differentiated limnology and water level variation intensely affected by the hydrological cycle. Therefore, we surveyed the influence of the flood pulse on fish communities that inhabit two canals that connect floodplain lakes to the Middle Solimões River. Particularly, we evaluated the hypothesis that the Solimões River flow direction is not perfectly parallel to its banks, which creates peripheral flows that direct water from the rivers to the floodplain lake canals. Our analysis indicated that the seasonal pattern is stronger than the spatial. Beside this, we observed that the positions of the canals in relation to the main river flow somehow affect the fish assemblages. Finally, we conclude that the flood pulse is the main structuring force acting on these fish communities.

A dinâmica dos sistemas de grandes rios com áreas inundadas adjacentes é fortemente influenciada pelo pulso de inundação, sendo este fenômeno o principal agente estruturador da biota, inclusive dos peixes, que utilizam este ambiente para a desova, alimentação, berçário e refúgio. Nesta região e em toda a bacia, a intensidade da vazão controla os fluxos internos. Na época da cheia, a forte vazão atua como uma barreira natural nos canais de ligação entre os lagos de várzea e o rio Solimões, com um fluxo no sentido rio-lago. Enquanto na seca, com a redução da intensidade da vazão, o fluxo se inverte. Estes canais são ambientes com características ecológicas especiais, profundamente afetadas pelo ciclo hidrológico. Neste trabalho, estudamos a influência do pulso de inundação sobre as comunidades de peixes existentes nos canais entre dois lagos de várzea e o Médio rio Solimões, avaliando a hipótese de que a direção do fluxo do rio Solimões não é perfeitamente paralelo às margens criando, desta forma, fluxos preferenciais que direcionam o sentido da correnteza para os canais dos lagos de várzea. Nossas análises indicaram que padrões sazonais predominam sobre padrões espaciais. Além disso, observamos que a posição do canal em relação ao fluxo da corrente do rio principal afeta de alguma maneira as assembléias de peixes. Finalmente, concluímos que o pulso de inundação é a principal força responsável pela estruturação destas comunidades de peixes.

Key words: Amazon, Seasonality, Freshwater fish.

\section{Introduction}

The biota of large river systems with adjacent floodplains are strongly affected by flood pulses, which are the main structuring force for fish communities (Freitas \& Garcez, 2004) that use floodplains for reproduction (Goulding, 1980; AraújoLima, 1985; Lowe-McConnel, 1999), feeding, nursery and refuge (Bayley, 1987; Lowe-McConnell, 1999).

The flood pulse promotes physical and chemical changes in the environment to which the organisms respond with morphological, anatomical, physiological, and ethological adaptations (Junk et al., 1989), which in turn affect the structure of fish communities (Junk, 1997).
Floodplains are important for the recruitment of several freshwater fish species (Sparks, 1995). In the Amazon basin, a great number of fish species enter the floodplain forest seasonally to feed on fruits, seeds and other terrestrial (allochthonous) resources (Goulding, 1980; Hamilton \& Lewis, 1987; Goulding et al., 1988).

The canals that connect floodplain lakes and the Solimões River are transient environments characterized by strong unidirectional currents, and the direction of the water flow is driven by the hydrological cycle (Freitas \& Garcez, 2004). During rising waters, the strong current blocks the water from the canals, acting as a natural barrier at the canals' mouth and creating a flow from river to lake. During droughts, with re-

Universidade Federal do Amazonas, Faculdade de Ciências Agrárias, Departamento de Ciências Pesqueiras, Av. Gen. Rodrigo Otávio Jordão Ramos 3000, Coroado, 69077-000 Manaus, AM, Brazil. ranieregarcez@yahoo.com; cefreitas@horizon.com.br 
duction in discharge, the flow is reversed or remains stationary.

In this work, the influence of a flood on the fish communities that inhabit two canals connecting floodplain lakes and the Middle Solimões River was evaluated. Particularly, we considered the hypothesis that the flow of the Solimões River is not perfectly parallel to the banks, which creates peripheral flows that change water direction in the canals, changing physical and chemical characteristics of the water and consequently influencing fish communities.

\section{Materials and Methods}

Surveyed Site. We surveyed two canals between the lakes Jacaré and Cururu and the Solimões River (Jacaré lake canal 03'36' $16^{\prime \prime}$ 'S and 609'06"W and Cururu lake canal 03³4'37"S and $60^{\circ} 48^{\prime} 27^{\prime \prime W}$ ), near the city of Manacapuru, Amazonas State, Brazil (Fig. 1). These canals are characterized by fluctuations in water level of about $10 \mathrm{~m}$, which result in defined flood and drought periods. The water level in the Solimões River is highest in June and lowest in November (Fig. 2).

Sampling Methodology. We conducted four samplings in the canals during the various phases of the hydrological cycle in 2004: rising waters/May, flood/July, receding waters/September and drought/November. To minimize the effects of gear selectivity, we used a set of five gill nets ( $30 \mathrm{~m}$ long and $2 \mathrm{~m}$ high) with mesh sizes of 30, 40, 50, 60 and $70 \mathrm{~mm}$ (opposite knots). Overall, gill nets were set for 18 hours, installed at 6:00 $\mathrm{PM}$ and removed at 12:00 AM. In addition, one gill net with the same dimensions and 30-mm mesh was drifted for 30 min- utes, two times per day, at 06:00 AM and 06:00 PM. A ring trap net with $20-\mathrm{mm}$ mesh and diameter of $2 \mathrm{~m}$ was used in the canals for one hour, two times per day, at 07:00 AM and 05:00 PM. Fish were identified according to Nelson (1994), Ferreira et al. (1998) and by experts. Some individuals were stored in the collection of the Laboratory of Fisheries Ecology at the Federal University of Amazonas. During samplings, some limnological data ( $\mathrm{pH}$, dissolved oxygen, conductivity and temperature at $60 \mathrm{~cm}$ deep) were also measured, every 4 hours (04:00 PM, 08:00 PM, 00:00 AM and 04:00 AM). The limnological data were obtained using the multi-function sensor PH-1500 equipment from Instrutherm. Representation of limnological reference values were expressed by averages and standard deviation.

Discharge measurements in the Solimões River were performed using the flow measurement method specific for large rivers (R. D. Instruments, 1995) using an Acoustic Doppler Current Profiler (ADCP) through Winriver software (R. D. Instruments, 2001). Water velocities were measured in two locations of the Solimões River, at $20 \%$ and $80 \%$ of the depth. Depth was measured using an echo-sounding machine.

Data analysis. We performed a detrended correspondence analysis (DCA), as proposed by Hill \& Gauch (1980), to identify spatial or seasonal patterns in the structure of fish assemblages in the canals. This analysis was chosen to avoid the arch effect, a common feature in the results of correspondence analysis (Manly, 2005). Statistica 6.0 software was used to perform the ordination analysis. Only axes with eigenvalues greater than 0.20 were interpreted, as recommended by Matthews (1998).

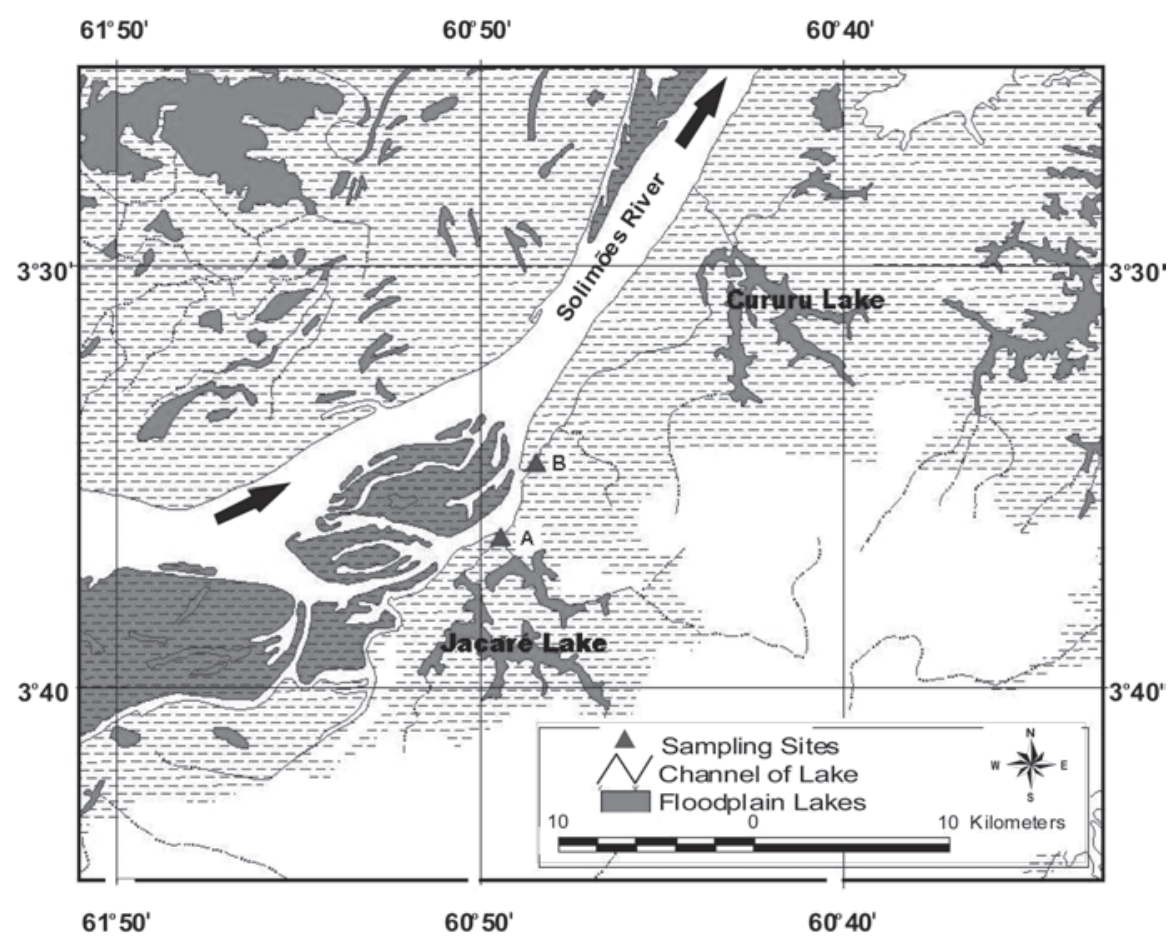

Fig. 1. Study area indicating the two sampling sites: (A) Jacaré lake canal and (B) Cururu lake canal. They are located in the municipality Manacapuru-Amazon-Brazil (PIATAM Project/ArcView program). 


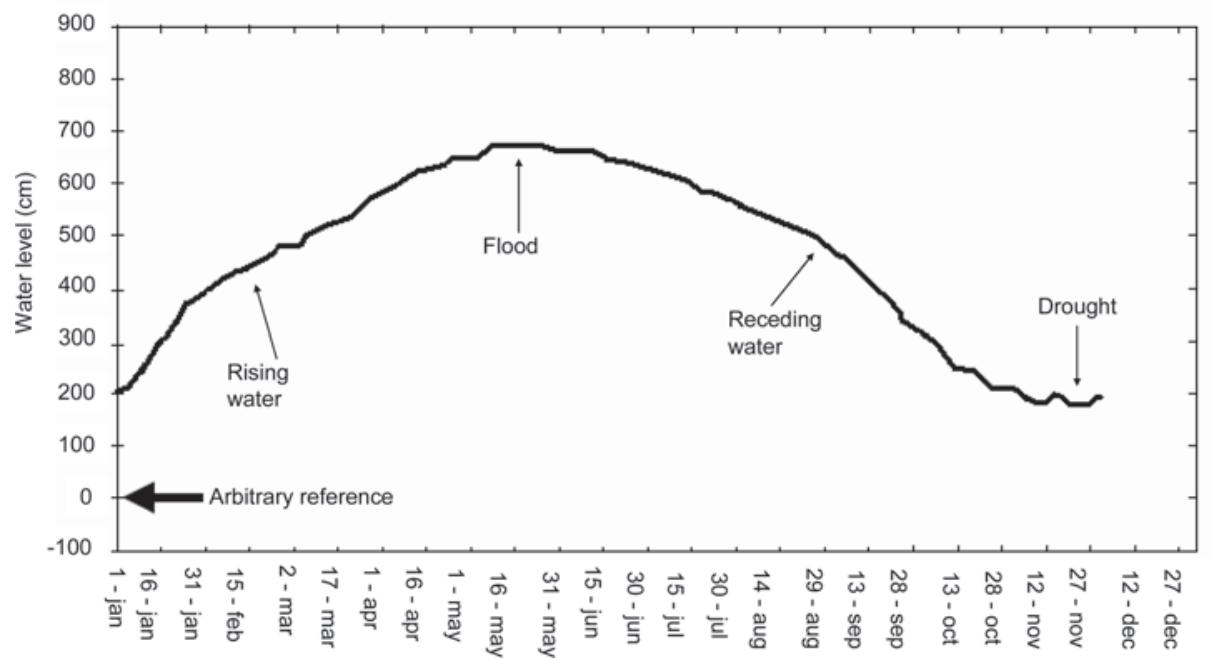

Fig. 2. Water level variations of Solimões River in 2004. Data obtained from ANA (National Water Agency).

\section{Results}

Limnological data varied along the flood cycle (rising waters, flood, receding waters and drought) and daily as well (night and day). Values of $\mathrm{pH}$ in the Jacaré lake canal ranged from 6.13 to 7.43 during rising waters and flood, and from 5.29 to 7.51 during receding waters and drought. In the Cururu lake canal, $\mathrm{pH}$ varied from 6.17 to 7.10 during rising waters and flood, and from 6.60 to 7.35 during receding waters and drought. Overall, $\mathrm{pH}$ in the Jacaré lake canal showed variations in all phases of the hydrological cycle and little variation daily, except for the drought period. At the Cururu lake canal, there were variations along the phases, but daily variation was low (Table 1 ).

Temperatures in the Jacaré lake canal ranged between $27^{\circ} \mathrm{C}$ and $30^{\circ} \mathrm{C}$ from rising waters to flood, and between $30^{\circ} \mathrm{C}$ and $34^{\circ} \mathrm{C}$ from receding waters to drought. In the Cururu lake canal, from rising waters to flood, it varied between $27^{\circ} \mathrm{C}$ and $29^{\circ} \mathrm{C}$ and from receding waters to drought, between $28^{\circ} \mathrm{C}$ and $32^{\circ} \mathrm{C}$ (Table 1 ). However, daily variation was low.
Conductivity at the Jacaré lake canal, ranged during rising waters and flood, from $0.016 \mu \mathrm{S} . \mathrm{m}^{-1}$ to $0.027 \mu \mathrm{S} . \mathrm{m}^{-1}$, respectively. During receding waters and drought, it varied from $0.011 \mu \mathrm{S} . \mathrm{m}^{-1}$ to $0.042 \mu \mathrm{S} . \mathrm{m}^{-1}$. In the Cururu lake canal, it ranged between $0.023 \mu \mathrm{S} . \mathrm{m}^{-1}$ and $0.028 \mu \mathrm{S} . \mathrm{m}^{-1}$, from rising waters to flood, and from $0.054 \mu \mathrm{S} . \mathrm{m}^{-1}$ to $0.076 \mu \mathrm{S} . \mathrm{m}^{-1}$ during receding waters and drought (Table 1). Daily variation was also low.

Values of dissolved oxygen were low during rising waters and flood in the Jacaré lake canal, ranging from $0.41 \mathrm{mg}^{-1}{ }^{-1}$ to $2.76 \mathrm{mg} . \mathrm{l}^{-1}$, whereas during receding waters and drought, dissolved oxygen levels increased, ranging from $1.50 \mathrm{mg} . \mathrm{l}^{-1}$ to $4.50 \mathrm{mg} . \mathrm{l}^{-1}$. In the Cururu lake canal, during rising waters and flood, oxygen levels ranged from $0.36 \mathrm{mg} . \mathrm{l}^{-1}$ to $2.00 \mathrm{mg} . \mathrm{l}^{-1}$ and for receding waters and drought, it varied from $0.40 \mathrm{mg}^{-l^{-1}}$ to $3.80 \mathrm{mg}^{-1} \mathrm{l}^{-1}$ (Table 1). Dissolved oxygen displayed distinct variations for each hydrological phase in both canals. However, in the Jacaré lake canal, estimated values showed an opposite tendency for night and day. In the Cururu lake canal, values during night and day were similar for each hydrological phase, except for drought, when it showed an oppo-

Table 1. Limnological data (averages) for the lake canals studied, including, $\mathrm{T}^{\circ} \mathrm{C}=$ temperature in degrees Celsius, $\mathrm{EC}=$ electrical conductivity, and $\mathrm{DO}=$ dissolved oxygen collected at night $(\mathrm{n}=2)$ and day $(\mathrm{n}=2)$ during the hydrological cycle. Where: $\mathrm{J}$ = Jacaré lake canal, C = Cururu lake canal, 1 = Rising water period, 2 = Flood period, 3 = Receding water period, 4 = Drought and \pm one standard deviation.

\begin{tabular}{|c|c|c|c|c|c|c|c|c|}
\hline & \multicolumn{4}{|c|}{ Jacaré Lake canal } & \multicolumn{4}{|c|}{ Cururu Lake canal } \\
\hline & $\mathrm{J} 1$ & $\mathrm{~J} 2$ & $\mathrm{~J} 3$ & $\mathrm{~J} 4$ & C1 & $\mathrm{C} 2$ & C3 & $\mathrm{C} 4$ \\
\hline \multicolumn{9}{|l|}{$\mathrm{pH}$} \\
\hline Day & $6.13( \pm 0.03)$ & $7.43( \pm 0.00)$ & $6.41( \pm 0.13)$ & $7.51( \pm 0.39)$ & $6.17( \pm 0.07)$ & $7.08( \pm 0.00)$ & $6.73( \pm 0.11)$ & $7.34( \pm 0.13)$ \\
\hline Night & $6.18( \pm 0.11)$ & $6.77( \pm 0.66)$ & $6.27( \pm 0.07)$ & $5.29( \pm 2$. & $6.20( \pm 0.04)$ & $7.10( \pm 0.00)$ & $6.60( \pm 0.07)$ & $7.35( \pm 2.21)$ \\
\hline \multicolumn{9}{|l|}{$\mathrm{T}^{\circ} \mathrm{C}$} \\
\hline Day & $30.25( \pm 2.12)$ & $26.95( \pm 1.41)$ & $33.90( \pm 2.89)$ & $32.00( \pm 1.98)$ & $28.40( \pm 1.27)$ & $29.50( \pm 0.00)$ & $29.05( \pm 0.99)$ & $33.05( \pm 2.40)$ \\
\hline Night & $27.65( \pm 1.76)$ & $27.40( \pm 0.00)$ & $31.40( \pm 0.63)$ & $30.35( \pm 0.35)$ & $27.50( \pm 0.21)$ & $27.70( \pm 0.77)$ & $27.80( \pm 0.77)$ & $30.95( \pm 0.56)$ \\
\hline \multicolumn{9}{|l|}{$\mathrm{EC}\left(\mu \mathrm{S} \cdot \mathrm{m}^{-1}\right)$} \\
\hline Day & $0.027( \pm 0.001)$ & $0.016( \pm 0.006)$ & $0.014( \pm 0.004)$ & $0.040( \pm 0.002)$ & $0.028( \pm 0.000)$ & $0.027( \pm 0.000)$ & $0.055( \pm 0$. & $0.075( \pm 0.001)$ \\
\hline Night & $0.027( \pm 0.000)$ & $0.017( \pm 0.000)$ & $0.011( \pm 0.001)$ & $0.042( \pm 0.001)$ & $0.028( \pm 0.001)$ & $0.023( \pm 0.001)$ & $0.054( \pm 0.000)$ & $0.076( \pm 0.003)$ \\
\hline \multicolumn{9}{|l|}{ DO (mg.l $\left.{ }^{-1}\right)$} \\
\hline Day & $0.41( \pm 0.092)$ & $1.60( \pm 1.061)$ & $4.30( \pm 2.616)$ & $2.50( \pm 2.899)$ & $0.36( \pm 0.127)$ & $2.00( \pm 0.000)$ & $1.20( \pm 0.354)$ & $0.40( \pm 3.394)$ \\
\hline Night & $2.76( \pm 0.057)$ & $2.65( \pm 0.000)$ & $1.50( \pm 0.212)$ & $4.50( \pm 1.061)$ & $0.38( \pm 0.113)$ & $1.70( \pm 0.141)$ & $1.40( \pm 1.485)$ & $3.87( \pm 0.919)$ \\
\hline
\end{tabular}


site tendency. Variations in oxygen concentrations in the Jacaré lake canal could be influenced by several factors such as the flood pulse, daily oscillations in primary production, bacterial activity, and decomposition of organic matter.

The analysis of the transverse outline of the Solimões
River revealed two distinct canals considering river depth. The first between 891 and $1943 \mathrm{~m}$ and the second between 1943 and $2698 \mathrm{~m}$, measured from the left bank (Fig 3). We also observed that water velocity was higher in the second canal. We hypothesized that the flow direction in this section of the

Table 2. Number of individuals captured for every species of the lake canals studied and codes used in the analyses. $(\mathrm{J}=$ Jacaré lake canal; C = Cururu lake canal; 1 = Rising water period; 2 = Flood period; 3 = Receding water period; 4 = Drought).

\begin{tabular}{|c|c|c|c|c|c|c|c|c|c|}
\hline \multirow{3}{*}{ Species } & \multicolumn{9}{|c|}{ Number of individuals sampled } \\
\hline & \multirow[b]{2}{*}{ Codes } & \multicolumn{4}{|c|}{ Jacare lake canal } & \multicolumn{4}{|c|}{ Cururu lake canal } \\
\hline & & $\mathrm{J} 1$ & $\mathrm{~J} 2$ & J3 & J4 & $\mathrm{C} 1$ & $\mathrm{C} 2$ & $\mathrm{C} 3$ & $\mathrm{C} 4$ \\
\hline \multicolumn{10}{|l|}{ Clupeiformes } \\
\hline \multicolumn{10}{|l|}{ Pristigasteridae } \\
\hline Pellona flavipinnis (Valenciennes, 1837) & Pf & 6 & 1 & 0 & 21 & 1 & 0 & 0 & 0 \\
\hline \multicolumn{10}{|l|}{ Characiformes } \\
\hline \multicolumn{10}{|l|}{ Anostomidae } \\
\hline Leporinus friderici (Bloch, 1794) & Lf & 1 & 0 & 0 & 29 & 0 & 0 & 13 & 3 \\
\hline Schizodon fasciatus Spix \& Agassiz, 1829 & $\mathrm{Sz}$ & 9 & 3 & 5 & 5 & 1 & 2 & 43 & 8 \\
\hline \multicolumn{10}{|l|}{ Characidae } \\
\hline Acestrorhynchus falcirostris (Cuvier, 1819) & Af & 1 & 0 & 3 & 3 & 0 & 0 & 0 & 0 \\
\hline Triportheus angulatus (Spix \& Agassiz, 1829) & Ta & 4 & 3 & 0 & 13 & 0 & 0 & 0 & 0 \\
\hline \multicolumn{10}{|l|}{ Curimatidae } \\
\hline Curimata inornata Vari, 1989 & $\mathrm{Cu}$ & 2 & 1 & 31 & 0 & 0 & 0 & 7 & 0 \\
\hline Curimata vittata (Kner, 1858) & $\mathrm{Cv}$ & 0 & 0 & 4 & 8 & 0 & 0 & 0 & 0 \\
\hline Potamorhina altamazonica (Cope, 1878) & $\mathrm{Pa}$ & 0 & 3 & 1 & 0 & 6 & 1 & 0 & 0 \\
\hline Potamorhina latior Spix \& Agassiz, 1829 & $\mathrm{Pl}$ & 11 & 1 & 3 & 0 & 5 & 0 & 0 & 0 \\
\hline Potamorhina pristigaster (Steindachner, 1876) & Po & 9 & 4 & 6 & 0 & 2 & 0 & 0 & 0 \\
\hline Psectrogaster amazonica Eigenmann \& Eigenmann, 1889 & Ps & 9 & 0 & 9 & 10 & 1 & 0 & 3 & 0 \\
\hline Psectrogaster rutiloides (Kner, 1858) & $\operatorname{Pr}$ & 0 & 0 & 10 & 12 & 0 & 0 & 1 & 0 \\
\hline \multicolumn{10}{|l|}{ Cynodontidae } \\
\hline Rhaphiodon vulpinus Agassiz, 1829 & $\mathrm{Rv}$ & 4 & 1 & 0 & 0 & 9 & 0 & 0 & 0 \\
\hline \multicolumn{10}{|l|}{ Erythrinidae } \\
\hline Hoplias malabaricus (Bloch, 1794) & $\mathrm{Hm}$ & 0 & 0 & 2 & 11 & 1 & 0 & 0 & 16 \\
\hline \multicolumn{10}{|l|}{ Hemiodontidae } \\
\hline Hemiodus argenteus Pellegrin, 1909 & $\mathrm{H}$ & 2 & 0 & 0 & 0 & 6 & 0 & 0 & 0 \\
\hline \multicolumn{10}{|l|}{ Prochilodontidae } \\
\hline Semaprochilodus insignis (Jardine \& Schomburgk, 1841) & $\mathrm{Si}$ & 0 & 1 & 22 & 0 & 0 & 0 & 0 & 0 \\
\hline \multicolumn{10}{|l|}{ Serrasalmidae } \\
\hline Colossoma macropomum (Cuvier, 1816) & Cs & 1 & 0 & 21 & 0 & 1 & 1 & 0 & 0 \\
\hline Metynnis argenteus Ahl, 1923 & My & 0 & 0 & 6 & 0 & 0 & 0 & 1 & 0 \\
\hline Mylossoma duriventre (Cuvier, 1818) & Md & 3 & 0 & 0 & 0 & 1 & 0 & 7 & 0 \\
\hline Pygocentrus nattereri Kner, 1858 & Pn & 20 & 0 & 15 & 7 & 0 & 0 & 0 & 0 \\
\hline Serrasalmus altispinis Merckx, Jégu \& Mendes dos Santos 2000 & Sl & 0 & 0 & 0 & 2 & 3 & 0 & 0 & 0 \\
\hline Serrasalmus eigenmanni Norman, 1829 & Se & 10 & 0 & 0 & 2 & 1 & 1 & 0 & 0 \\
\hline Serrasalmus elongatus Kner, 1858 & $\mathrm{~S}$ & 7 & 1 & 20 & 3 & 0 & 0 & 0 & 0 \\
\hline Serrasalmus spilopleura Kner, 1858 & Ss & 6 & 0 & 5 & 2 & 0 & 0 & 1 & 0 \\
\hline Pristobrycon calmoni (Steindachner, 1908) & Pc & 0 & 0 & 2 & 0 & 1 & 0 & 7 & 0 \\
\hline Siluriformes & & & & & & & & & \\
\hline Ageneiosidae & & & & & & & & & \\
\hline Ageneiosus ucayalensis Castelnau, 1855 & $\mathrm{Au}$ & 0 & 0 & 0 & 0 & 12 & 1 & 0 & 0 \\
\hline Auchenipteridae & & & & & & & & & \\
\hline Trachelyopterus galeatus (Linnaeus, 1766) & $\operatorname{Tg}$ & 3 & 1 & 0 & 0 & 4 & 0 & 1 & 4 \\
\hline Callichthyidae & & & & & & & & & \\
\hline Hoplosternum littorale (Hancock, 1828) & $\mathrm{Hl}$ & 4 & 1 & 3 & 10 & 0 & 0 & 0 & 0 \\
\hline Doradidae & & & & & & & & & \\
\hline Nemadoras sp. & $\mathrm{N}$ & 0 & 0 & 0 & 0 & 0 & 0 & 16 & 0 \\
\hline Pterodoras lentiginosus (Valenciennes, 1817) & $\mathrm{Pt}$ & 0 & 0 & 0 & 0 & 0 & 1 & 0 & 5 \\
\hline Hypophthalmidae & & & & & & & & & \\
\hline Hypophthalmus fimbriatus Kner, 1858 & Hf & 1 & 0 & 0 & 0 & 0 & 0 & 0 & 0 \\
\hline Loricariidae & & & & & & & & & \\
\hline Loricariichthys maculatus (Bloch, 1794) & Lm & 0 & 0 & 0 & 1 & 0 & 0 & 1 & 5 \\
\hline Pterygoplichthys pardalis (Castelnau, 1855) & $\mathrm{Pp}$ & 2 & 0 & 9 & 18 & 0 & 0 & 5 & 13 \\
\hline Pimelodidae & & & & & & & & & \\
\hline Pimelodus blochii Valenciennes, 1840 & $\mathrm{~Pb}$ & 1 & 0 & 0 & 0 & 0 & 1 & 19 & 0 \\
\hline Total & & 116 & 21 & 177 & 157 & 55 & 8 & 125 & 54 \\
\hline
\end{tabular}




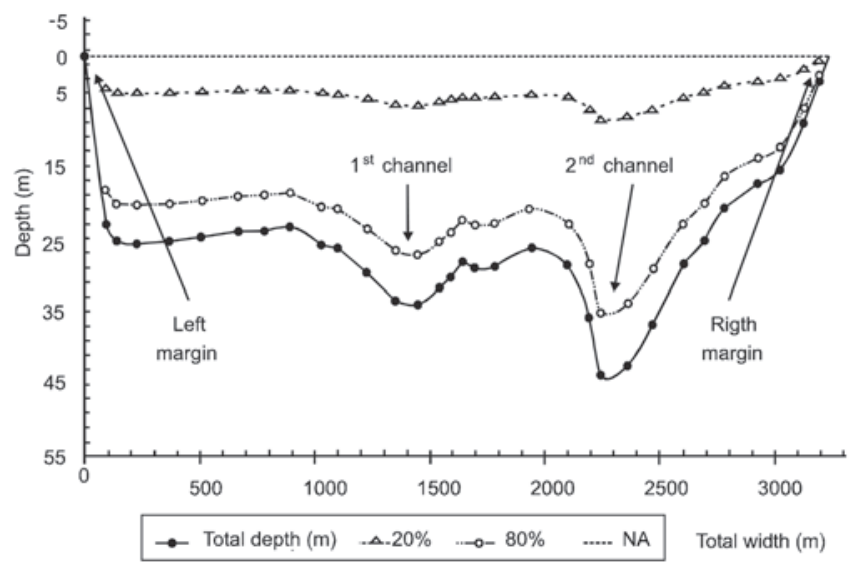

Fig. 3. Transverse profile obtained from the Solimões River using Winriver software. (NA = water level, $20 \%$ and $80 \%$ of the depth).

river is not perfectly parallel to the banks. This creates peripheral flows that direct the Solimões River current to the floodplain lake canals, consequently changing the hydrological and limnological attributes which influence the resident fish communities.

A total of 713 individuals belonging to four orders, 12 families, 25 genera and 34 species were collected. Characiformes was the most abundant order, followed by Siluriformes, and Clupeiformes. Characiformes was also the most diverse group, represented by 24 species. The most abundant families were Serrasalmidae, Curimatidae and Loricariidae, and more abundant species were Schizodon fasciatus, Pterygoplichthys pardalis and Leporinus friderici (Table 2).

The first two axes of the detrended correspondence analysis (DCA), $\left(\lambda_{1}=0.5628\right.$ and $\left.\lambda_{2}=0.1053\right)$ indicated different species compositions for the samples (canals and seasons). Hydrological cycle is the main structuring force, represented by axis 1 , because on the right side of the ordination are located samples taken during rising waters and flood (seasonal pattern stronger than spatial). For instance, on the left side are located the samples of receding waters and drought, but this pattern is more evident for the Cururu lake canal (Fig. 4), indicating the existence of a spatial pattern. Axis 2 of the DCA was not interpreted because of the low eigenvalue which represents low variability on it.

The differences among samples collected during rising waters and flood and those during receding waters and drought in the Cururu lake canal were determined by the high abundance of Ageneiosus ucayalensis (Au), Rhaphiodon vulpinus (Rv), Hemiodus argenteus $(\mathrm{H})$ and Potamorhina altamazonica $(\mathrm{Pa})$, all abundant in rising water and flood. Meanwhile, Schizodon fasciatus (Sz), Nemadoras sp (N), Pimelodus blochii $(\mathrm{Pb})$, Loricariichthys maculatus (Lm) and Pterygoplichthys pardalis ( $\mathrm{Pp}$ ) were abundant in receding waters and drought (Fig. 5; Table 2). In the Jacaré lake canal, Pygocentrus nattereri (Pn), Potamorhina latior (Pl), Serras-

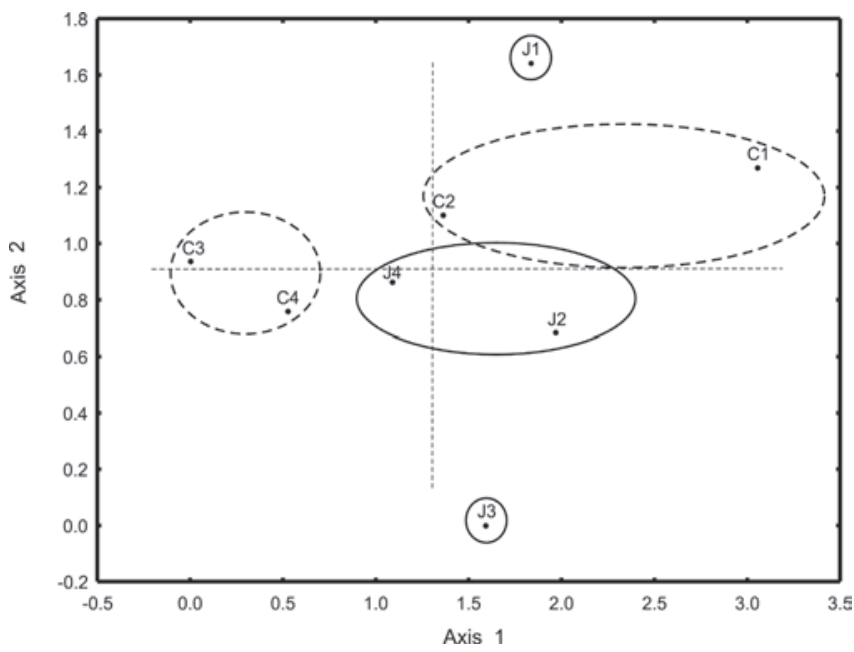

Fig. 4. Ordination of the samples (canal and season) of the hydrological cycle, where: $\mathrm{J}=$ Jacaré lake canal, $\mathrm{C}$ = Cururu lake canal, 1 = rising waters, 2 = flood, 3 = receding waters, and $4=$ drought.

almus eigenmanni (Se) and Potamorhina pristigaster (Po) were abundant in rising waters and flood.

\section{Discussion}

Floodplain areas are periodically inundated by lateral inflow of water from rivers or lakes and/or by direct precipitation (Junk et al., 1989). These areas are common along the Solimões-Amazon River, from Puallpa in Peru to the river estuary in Brazil, where inundations are characterized by amplitude, and intensity varies along the trajectory of the river. The connection between the main river channel and floodplain lakes is made by a huge number of canals that are inhabited by migratory and resident species (Freitas \& Garcez, 2004).

In both canals studied, we demonstrated a dominance of Characiformes over Siluriformes. This trend is well reported in South American rivers, lakes, reservoirs and floodplains

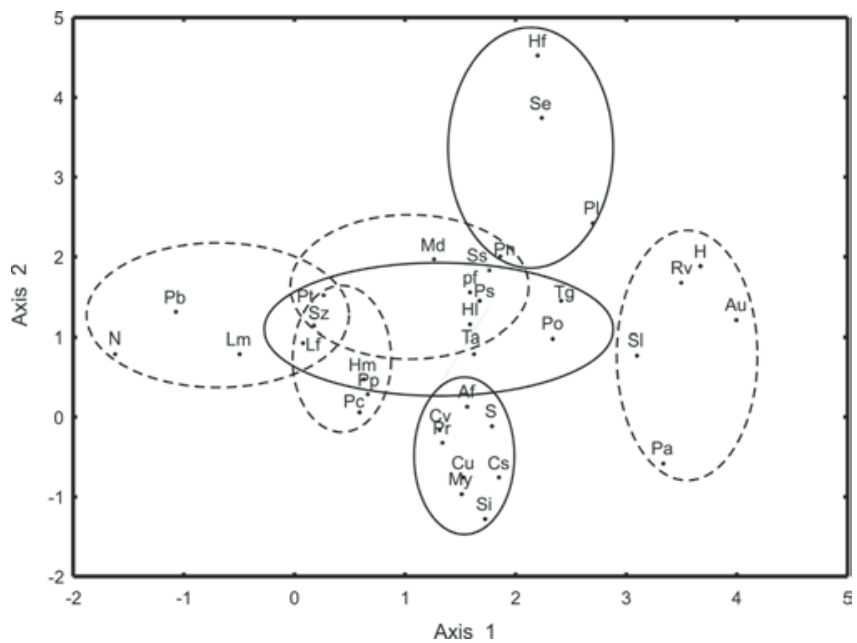

Fig. 5. Ordination of fish species, with respective codes, by detrented correspondence analysis. (---- Cururu lake canal, — Jacaré lake canal). 


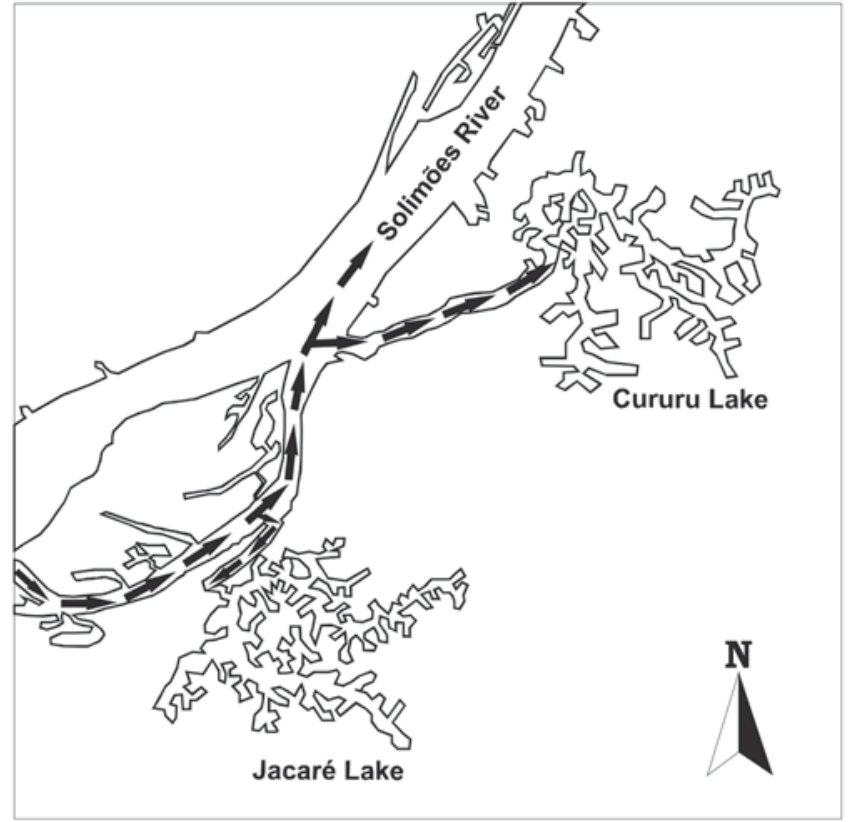

Fig. 6. Representative map showing the flow of the Solimões River in direction to the Jacaré and Cururu lake canals.

(Okada, 1995; Lowe-McConnell, 1999; Freitas \& Garcez, 2004). In addition, Veríssimo (1994) found a dominance of small Characiformes in a floodplain lagoon of the Paraná River, and he attributed this result to the high capacity of these fish to obtain oxygen from the surface.

Tropical rivers are known for the presence of long-distance migratory species. These fish disperse or spawn in the main canal of rivers (tributaries) or in floodplain areas, resulting in high biomass in the main canal during receding or low water periods (Godoy, 1967; Bonetto et al., 1969; Bayley, 1973; Ribeiro, 1983; Winemiller \& Jepsen, 1998). Dispersion movements are performed to avoid adverse conditions (high temperature and low dissolved oxygen) in the floodplain during these periods.

Even with the canal linking to the main river (Solimões River), which allows fish to escape adverse conditions, a great number of species remained in the canals. We believe that this occurred because several species had adaptations that enabled them to thrive in harsh conditions, as mentioned by Lowe- McConnell (1999).

During the periods of rising waters and flood, the number of fish caught was lower than during receding waters, also due to dispersion. Fish species used the canals and the floodplain areas for lateral migration, and the water flow running from the river towards the lake. However, in the period of receding waters, flow changed direction from the lake towards the river, and several fish left the lakes. In those canals, water flow was slow and predators (Serrasalmus sp.) were abundant.

For the drought period, water flow in the Jacaré lake canal stopped and the number of captured fish was high. Fish appeared to show strong stress due to low concentrations of dissolved oxygen and to the great effort to avoid predation.
Meanwhile, at the Cururu lake canal, there were concentrations of fish due to space reduction. Some parts dried out completely and fish died. Resident species, such as Pterygoplichthys pardalis, Nemadoras sp., Pterodoras lentiginosus, Trachelyopterus galeatus and Serrasalmus sp. demonstrated great adaptability to inhabit these environments during low water periods.

In both canals, the positions in relation to the main river flow are different. Cururu lake canal is lateral (high water velocity) and Jacaré lake canal is parallel in relation to the water flow (low water velocity) (Fig. 6). These positions somehow affect water physical and chemical parameters. Consequently, the fish assemblage reacts to these variations.

We believe that the flood pulse and the river flow are the main structuring factors that influence the fish communities that inhabit these floodplain lakes, corroborating the work of Freitas \& Garcez (2004), since the dominance of abiotic factors result, in general, in community structure with a stochastic pattern.

\section{Acknowledgments}

We thank Dr. James R. Kahn for helpful comments on the manuscript, Dr. Jansen Alfredo Sampaio Zuanon for help with the identification of fish, and the PIATAM project FINEP/ PETROBRAS and PYRA Program for supporting the research.

\section{Literature Cited}

Araújo-Lima, C. A. R. M. 1985. Distribuição espacial e temporal das larvas de Characiformes em um setor do Rio Amazonas/ Solimões, próximo a Manaus, Am. Unpublished M.Sc. Dissertation, INPA/UFAM, Manaus. 84p.

Bayley, P. B. 1973. Studies on the migratory characin, Prochilodus platensis Golmberg 1889, (Pices, Characoidei) in the river Pilcomayo, South America. Journal Fish Biology, 5: 25-40.

Bayley, P. B. 1987. Factors affecting growth rates of young tropical floodplain fishes: Seasonality and density - Dependence. Environmental Biology of Fishes, 21: 127-142.

Bonetto, A. A., E. Cordoviola, C. Pignalberi \& O. Oliveros. 1969. Ciclos hidrológicos Del rio Paraná y las poblaciones de peces contenidas en las cuencas temporales de su valle de inundación. Physis, 29: 215-223.

Ferreira, E. J. G., J. Zuanon \& G. M. Santos. 1998. Peixes comerciais do médio Amazonas - Região de Santarém, PA. Imprensa Oficial, Brasília. 211p.

Freitas, C. E. C. \& R. C. S. Garcez, 2004. Fish communities of natural canals between floodplain lakes and Solimões-Amazonas River. Acta Limnológica Brasiliensia, 16(3): 273-280.

Godoy, M. P. 1967. Dez anos de observação sobre periodicidade migratória de peixes do Rio Mogi Guassu, Revista Brasileira de Biologia, 27: 1-12.

Goulding, M. 1980. The Fishes and the Forest: Explorations in Amazonian Natural History. Berkley, California. University of California Press, 280p.

Goulding, M., M. L. Carvalho \& R. J. G. Ferreira. 1988. Rio Negro: rich life in poor water: Amazonian diversity and foodchain ecology as seen through fish communities. The Hague: SPB Academic Publishing, 200p.

Hamilton, S. K. \& W. M. Lewis Jr. 1987. Causes of seasonality in 
the chemistry of a lake on the Orinoco River floodplain, Venezuela. Limnology and Oceanography, 32: 1277-1290.

Hill, M. O. \& H. G. Gauch. 1980. Detrended correspondence analysis, an improved ordination technique. Vegetatio, 42: 4758.

Junk, W. J. 1997. General aspects of floodplain ecology with special reference to Amazonian floodplains. Pp. 3-20. In: Junk, W. J. (Ed.). The Central Amazon Floodplain: ecology of a pulsing system. Springer-Verlag. Ecological studies. 126p.

Junk, W. J., P. B. Bayley \& R. E. Sparks. 1989. The flood pulse concept in river - floodplain systems, Pp. 110-127. In: D. P. Dodge, D. P. (Ed.). Proceedings of the International Large River Symposium. Canadian Special Publications of Fisheries and Aquatic Science, 106.

Lowe- McConnell, R. H. 1999. Estudos ecológicos de comunidades de peixes tropicais. Editora da Universidade de São Paulo EDUSP. 535p.

Manly, B. F. J. 2005. Multivariate Statistical Methods: A Primer, 3rd edition. Chapman \& Hall/CRC, Boca Raton, Florida. 214p.

Matthews, W. J. 1998. Patterns in Freshwater Ecology. New York, Chapman \& Hall, 756p.

Nelson, J. S. 1994. Fishes of the World. $3^{\text {rd }}$ ed. John Wiley \& Sons, New York. 600p.

Okada, K.O., A. A. Agostinho, M. Petrere Jr. \& T. Penczak. 2003.
Factors affecting fish diversity and abundance in drying pools and lagoons in the upper Paraná river basin, Brazil. Ecohydrology \& Hydrobiology 3(1): 97-110.

R. D. Instruments, 1995. Direct reading and self contained broadband acoustic Doppler current profiler technical manual for Firmware version 5.XX: R.D. Instruments, Inc., San Diego, California. 460p.

R. D. Instruments, 2001. WinRiver User's Guide: San Diego, R.D. Instruments. 117 p.

Ribeiro, M. C. L. B. 1983. As migrações dos jaraquis (Pices, Prochilodontidae) no rio Negro, Amazonas, Brasil. Unpublished M.Sc. Dissertation. INPA/FUA. Manaus, Amazonas, Brasil. 192p.

Sparks, R. E. 1995. Need for ecosystems management of large rivers and their floodplains. Bioscience, 45: 168-181.

Veríssimo, S. 1994. Variações na composição da ictiofauna em três lagoas sazonalmente isoladas na planície de inundação do alto rio Paraná, ilha do Porto Rico, PR-Brasil. Unpublished M.Sc. Thesis. UFSCAR, São Carlos. 77p.

Winemiller, K. O. \& D. B. Jepsen. 1998. Effects of seasonality and fish movement on tropical river food webs. Journal of Fish Biology, 53: 267-296. 